\title{
Hydropower, Geothermal, and Ocean Energy
}

\author{
Ralph E.H. Sims (Massey University, New Zealand, and \\ International Energy Agency, France)
}

\begin{abstract}
Some forms of renewable energy have long contributed to electricity generation, whereas others are just emerging. For example, large-scale hydropower is a mature technology generating about $16 \%$ of global electricity, and many smaller scale systems are also being installed worldwide. Future opportunities to improve the technology are limited but include upgrading of existing plants to gain greater performance efficiencies and reduced maintenance. Geothermal energy, widely used for power generation and direct heat applications, is also mature, but new technologies could improve plant designs, extend their lifetimes, and improve reliability. By contrast, ocean energy is an emerging renewable energy technology. Design, development, and testing of a myriad of devices remain mainly in the research and development stage, with many opportunities for materials science to improve design and performance, reduce costly maintenance procedures, and extend plant operating lifetimes under the harsh marine environment.
\end{abstract}

\section{Scope}

Renewable energy accounted for over $15 \%$ of the world's primary energy supply in 2004 (Table $\mathbf{I}^{1}$ ), although about half of this amount came from traditional biomass used for cooking and heating for over two billion people in developing countries. Large hydropower generated $16 \%$ of total global electricity, similar to the percentage generated from nuclear power. (Proportions of electricity production were calculated from the energy content of the electricity generated rather than from the installed capacity of the power stations.) Other "new" renewables, mainly wind, geothermal, and biomass, produced just $2.5 \% .^{2}$ Together with solar thermal systems, biomass and geothermal also provided a significant proportion of the total heat demand, although statistical data are difficult to access and therefore uncertain. The business-as-usual scenario of continued growing energy demand from the World Energy Outlook 2006 of the International Energy Agency (IEA) predicted that renewable energy technologies (RETs) will have declined to a $13.7 \%$ share of global primary energy by 2030 because of a greater proportion of demand growth projected to be met by fossil fuels. ${ }^{2}$ Even under the Alternative Policy scenario of the IEA report, RETs will not increase their market share greatly during the coming decades without continued and sustained policy intervention.

Other articles in this issue have discussed in detail renewable resources including solar (see the works by Ginley, Green, and Collins; Mehos; Tritt, Böttner, and Chen; Soboyejo and Taylor; and Palucka), wind (Hayman, Wedel-Heinen, and Brøndsted), and biomass (Farrell and Gopal; Wyman; and Gust, Moore, Moore, Vermaas, and Kramer). This article concentrates on several others, including large-scale hydropower and geothermal first-generation mature technologies; second-generation mini- and micro-hydropower and ground heat pump technologies; and emerging third-generation wave, tidal range, and ocean current power generation technologies. The two mature technologies have been able to compete in today's energy markets in many countries without present policy support, although older plants have historically received consider- able government investment (as have nuclear and thermal power plants). New and emerging technologies under development often benefit from incentives and government support measures to encourage deployment. ${ }^{3}$ In addition, wind, solar, and wave energy are variable resources, making grid integration complex and constrained. Hydropower and geothermal, as well as predictable tidal energy, can be used as the baseload in a portfolio of renewable energy generation options.

Renewable energy systems can contribute to protection of the environment and security of the energy supply, as they provide a diversified portfolio of energy supply using local resources. ${ }^{4}$ These and other benefits were defined in a political declaration by 154 nations at the Renewables 2004 conference held in Bonn, Germany. ${ }^{5}$ As a result, there has been increasing support for renewable energy deployment in developing countries, not only from international development and aid agencies, but also from large and small local financiers, with additional backing from donor governments and market facilitators to reduce their risks. As an example, total donor funding pledges in the Bonn Renewables 2004 Action Programme amounted to about $\$ 50$ billion. $^{5}$

In many countries, sites using the best hydro and geothermal resources have already been utilized (often termed the "lowhanging fruit"). Obtaining resource consents for other sites is more of a challenge. Wherever hydropower expansion is occurring, major social disruptions, ecological impacts on existing river ecosystems and fisheries, and related evaporative water losses are stimulating public opposition. Similarly, some geothermal field developments have been criticized for being unsustainable in the long term and for causing land subsidence leading to damage to buildings and infrastructure. Placing energy devices in oceans that have a wide range of stakeholders - some with concerns over safe navigation, threats to fishing, and the possible endangering of marine life - could present a challenge to developers wishing to obtain resource use permits, but this issue is yet to be tested. Therefore, for all three technologies, obtaining resource use permits might become more challenging 


\section{Table I: Technical Potential Energy Resource and Fluxes Available, Potential Associated Carbon, and Projected Costs (in 2006 Dollars) in $\mathbf{2 0 3 0}$ for a Range of Energy Resources and Carriers.}

\begin{tabular}{|c|c|c|c|c|c|}
\hline \multirow{2}{*}{$\begin{array}{l}\text { Energy Resources } \\
\text { and Carriers }\end{array}$} & \multirow{2}{*}{$\begin{array}{l}\text { Technical Potentiala } \\
\text { (EJ) }\end{array}$} & \multirow{2}{*}{$\begin{array}{l}\text { Rate of Use in } 2005^{b} \\
\text { (EJ/year) }\end{array}$} & \multirow{2}{*}{$\begin{array}{l}\text { Present Energy } \\
\text { Costs }^{c}(\$, 2005)\end{array}$} & \multicolumn{2}{|c|}{ Projected Costs in 2030} \\
\hline & & & & Investment ${ }^{d}(\$ / W e)$ & Generation (\$/MWh) \\
\hline Oil & $10,000-35,000^{\mathrm{e}}$ & 160 & $\begin{array}{c}\sim 9 / \mathrm{GJ} \sim 50 / \mathrm{bbl} \\
\sim 48 / \mathrm{MWh}\end{array}$ & $\mathrm{n} / \mathrm{a}$ & $50-100$ \\
\hline Natural gas & $18,000-60,000$ & 100 & $\sim 5-7 / \mathrm{GJ} \sim 37 / \mathrm{MWh}$ & $0.2-0.8$ & $40-60+\operatorname{CCS} 60-90$ \\
\hline Coal & 130,000 & 120 & $\sim 3-4.5 / \mathrm{GJ} \sim 20 / \mathrm{MWh}$ & $0.4-1.4$ & $40-55+\operatorname{CCS} 60-85$ \\
\hline Nuclear power & $7,400^{f}$ & 26 & $10-120$ & $1.5-3.0$ & $25-75$ \\
\hline Hydro (>10 MW) & 1,250 & 25 & 20-100/MWh & $1.0-3.0$ & $30-70$ \\
\hline Solar PVg & 40,000 & 0.2 & 250-1,600/MWh & $0.6-1.2$ & $60-250$ \\
\hline Solar CSPh & 50 & 0.03 & 120-450/MWh & $2.0-4.0$ & $80-180$ \\
\hline Wind & 15,000 & 1 & 40-90/MWh & $0.4-1.2$ & $30-80$ \\
\hline Geothermal & 50 & 2 & 40-100/MWh & $1.0-2.0$ & $30-80$ \\
\hline Ocean & large & 0 & 80-400/MWh & $?$ & 70-200 \\
\hline $\begin{array}{l}\text { Biomass (modern } \\
\text { heat and power) }\end{array}$ & 250/year & 9 & $\begin{array}{l}\text { 30-120/MWh } \\
\text { 8-12/GJ }\end{array}$ & $0.4-1.2$ & $30-100$ \\
\hline
\end{tabular}

Source: Reference 1

aGeneralized potential for extractable energy: for fossil fuels, includes remaining extractable resources; for renewable energy, includes likely cumulative value by 2030. bHydro and wind are treated as equivalent energy to fossil and biomass because the conversion losses are much less (www.iea.org/textbase/stats/questionaire/faq.asp) (accessed January 2008).

cPrices volatile. Data include old and new plants operating in 2006 and assume electricity costs for conversion efficiencies of $35 \%$ for fossil, nuclear, and biomass. dExcluding carbon dioxide capture and storage (CCS).

encludes probable and unconventional oil and gas reserves.

${ }^{t}$ Assuming all remaining uranium, either used in once-through thermal reactors or recycled through light water reactors, at $\$ 130 / \mathrm{kg}$.

gPhotovoltaics.

nConcentrating solar power.

in the future and might pose a constraint to further deployment as a result of these environmental concerns.

\section{Hydropower}

Large ( $>10$ megawatt, MW) hydroelectricity systems accounted for over 2,800 terawatt-hours (TWh) of consumer energy in 2004, provided $90 \%$ of total renewable electricity, and avoided releasing over 2 gigatons $(\mathrm{Gt})$ of $\mathrm{CO}_{2}$ into the atmosphere if the same electricity had been generated from coal-fired power stations. Hydropower projects under construction could increase their share of total renewable electricity by about $4.5 \%$ upon completion ${ }^{6}$ and new projects could be deployed to provide a further $6,000 \mathrm{TWh} /$ year or more of electricity economically, mainly in developing countries. ${ }^{7}$ Small, mini- and micro-hydropower systems, usually run-of-river schemes without dams, have provided electricity to many rural communities in developing countries such as Nepal. The world total generation output of these smaller systems is uncertain, with predictions ranging between 4 and $250 \mathrm{TWh} /$ year, where the latter represents about $9 \%$ of total world hydropower output.

Typical construction costs for large hydropower plants are relatively high at between $\$ 1,000$ and $\$ 2,500 / \mathrm{kW}$, but the best sites (having high hydrostatic heads; close proximity to load demand; good year-round flow rates; low operating, maintenance, and fuel costs; and high capacity factors) can generate power for about $\$ 30-40 / \mathrm{MWh},{ }^{7,8}$ which competes well with power from coal-fired plants. When international carbon trading begins in earnest, they will compete even more, with the possible exception of plants in the tropics where any flooded vegetation can result in methane production. Smaller hydropower plants, especially those installed in less favorable terrain at a distance from the load, could cost more to generate and transmit the power and, if they lacked a reservoir, would be subject to daily and seasonal flow fluctuations and periods of drought.

Side benefits such as creating irrigation resources, recreational lakes, and flood control systems need to be taken into account for any given development. However, questions have arisen over the environmental and social impacts from development of large hydropower schemes, even from environmental groups that usually support renewable energy projects. Greenhouse gas emissions result from the manufacture of cement used during the construction of hydro dams and also, in some circumstances, from the release of methane from reservoirs after the flooding of vegetation. Such effects vary considerably with average ambient temperature and region, so sustainability guidelines have been produced to promote greater consideration of environmental, social, and economic sustainability in the assessment of new hydropower projects, as well as the management and operation of existing hydropower facilities. ${ }^{9}$

About $75 \%$ of water reservoirs in the world were originally built for irrigation, flood control, and urban water supply schemes, so small hydropower generation retrofits could be added to many of them (Figure 1). The global technical potential of such hydropower projects is thought to be about 150-200 gigawatts $(\mathrm{GW})$, with many unexploited resource sites available. Generating costs from such sites could lie in the range of $\$ 20-90 /$ MWh, excluding any additional costs needed for grid connection and power distribution. Such costs can be prohibitive in remote areas, even for mini-grids where no current infrastructure exists. Hence, in developing countries, some form of financial assistance for these social costs is often necessary from governments or aid programs.

The relatively high level of flexible control of hydropower plants enables load changes in electricity demand to be followed. Some schemes, such as the $12.6 \mathrm{GW}$ Itaipu plant in 


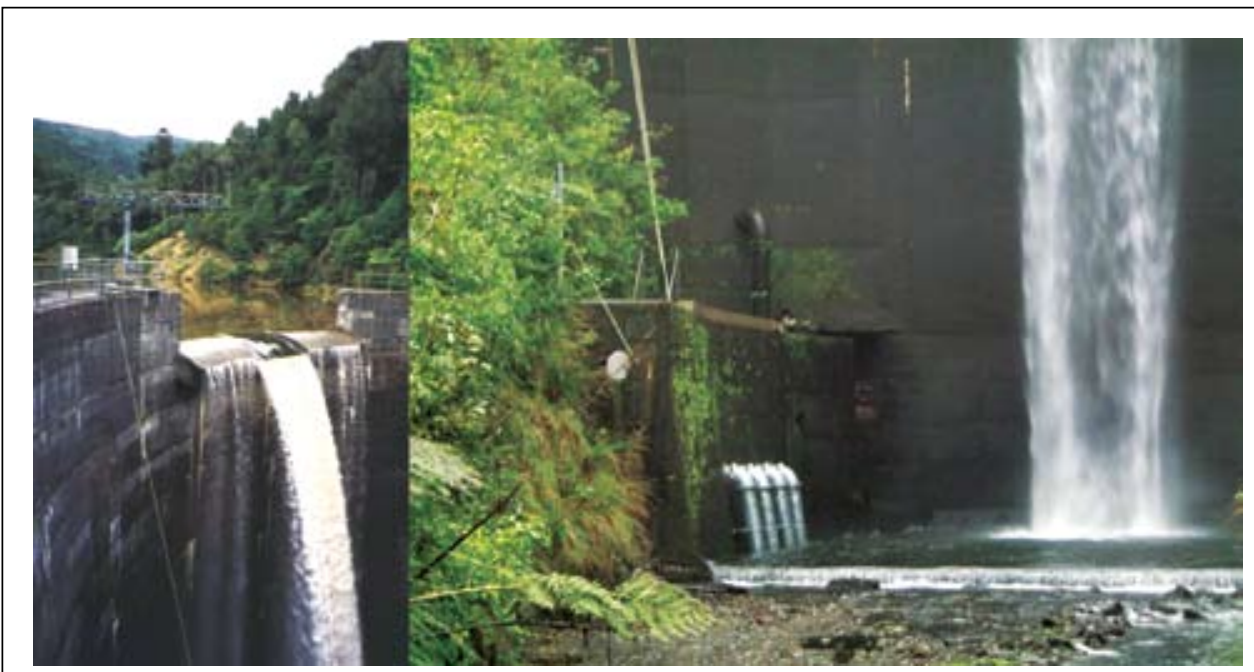

Figure 1. Water supply reservoir for Palmerston North, New Zealand, exemplifies how existing dams can also be retrofitted for power generation. The housing at the foot of the 60 -year-old dam contains four reverse motors acting as turbines generating $700 \mathrm{~kW}$ as installed in 2004 gate/guide vane bearings, as well as bearings for operation of the intake, spillway, and lock gates and fish screen and trash rake bearings.

Evaluations of hybrid hydro/ wind systems, hydro/hydrogen systems, low-head run-of-river systems, and pumped (by wind or thermal power plants) river storage to offset peak power are under review through the IEA Hydropower Implementing Agreement. ${ }^{10}$ This international collaboration includes a task specifically directed toward small hydropower systems.

Opportunities exist for further development of materials to reduce blade wear and corrosion from sedimentation and cavitation damage, of thrust bearings, of stator core materials, of remote operation systems, of turbine blade configurations, and of novel designs for

Brazil/Paraguay, are run as baseload generators with an average capacity factor of $>80 \%$, whereas others (as in a $24 \mathrm{GW}$ pumped storage plant in Japan) are used mainly as fast-response peaking plants giving a capacity factor closer to $40 \%$. Technology exists to continually match the power output of mini-hydropower systems to a varying load and hence save unnecessary wear of the turbine and rotors, but it is not widely employed.

\section{Research, Development, and Demonstration (RD\&D) Requirements}

Refitting existing plants with more powerful and efficient turbine designs and with blades made from more wear-resistant materials can be cost-effective whatever the plant scale. Increased blade wear occurs as a result of small solid particles in the water, including debris passing through the screens, and even from fine ash particles from volcanic activity close to the water source. Because all of these particles are very hard to filter out, using hardened alloy coatings to reduce blade wear could be a solution.

Bearings designed to meet the stringent demands of hydropower applications for high load capacity, low wear rate, minimal friction, self-lubrication, and long service life have been developed (see, for example, www.gbbearings.com-accessed January 2008). These can be based on fiber/resin composite materials that combine the lubricating properties of a polytetrafluoroethylene liner bonded to a high-strength, glass-fiber-filled, epoxy resin backing. They are available in both flat and cylindrical forms for several hydropower applications when using a range of Francis, Kaplan, and Pelton turbine designs as selected for any given site based on the flow and head (pressure) characteristics of the hydro resource. (Briefly, with the Francis turbine, also called a radialflow turbine, water flows from the outer circumference over curved blades toward the center of the runner. The Kaplan turbine is an axial-flow turbine that uses a propeller-shaped runner and operates like a boat propeller but in reverse mode. The Pelton design consists of a wheel with spoon-shaped buckets that change the direction and velocity of passing water, thus gaining its momentum. These turbine designs are typically applied in systems with water heads of $2-200 \mathrm{~m}, 2-30 \mathrm{~m}$, and $100-250 \mathrm{~m}$ or above, respectively, i.e., approximately 6-660ft., 6-100 ft., and 330-820 ft.) Applications include servo-motor bearings, ring sliding segments, and wicket low-head and in-stream devices. ${ }^{11}$ Improved technologies are also under development for smaller scale systems to reduce costs and wear. For example, one New Zealand manufacturer ${ }^{12}$ has converted reject washing machine motors into $1 \mathrm{~kW}$ generators driven by a Pelton wheel turbine using throw-away, molded plastic blades. These can be replaced every few months depending on the operating pressure and sedimentation in the stream (Figure 2).

\section{Geothermal}

Geothermal heat from low-temperature fields located in sedimentary basins of geologically stable platforms has long been used for district urban heating, industrial processing, domestic water and space heating, leisure, and balneotherapy (thermal bath therapy) applications. Useful heat and power produced globally totals about 2 exajoules (EJ)/year. Higher temperature fields located in geodynamically active regions with temperatures above $250^{\circ} \mathrm{C}$ utilize high-temperature natural steam or a steam/brine mixture under pressure (Figure 3). Where this resource can be reached by drilling to depths of less than $2 \mathrm{~km}$, electricity generation using steam turbines can usually be achieved directly at competitive prices.

The installed geothermal generation capacity of over $8.9 \mathrm{GWe}$ (gigawatts electrical) in 24 countries produced $56.8 \mathrm{TWh}(0.3 \%)$ of global electricity in 2004 and is growing at about $20 \%$ per year. ${ }^{13}$ Proven resources of over $10 \mathrm{GW}$ are yet to be utilized; from these resources, over $1,000 \mathrm{TWh} /$ year of electricity could be produced, to possibly reach about $2 \%$ of total global electricity generation by $2030 .{ }^{6}$ Binary power plants (using low-boiling-point heat-transfer fluids and heat exchangers) and organic Rankin cycle systems (using low-boiling-point heat-transfer fluids) are more recent developments to suit lower-enthalpy (temperature and heat concentration) fields, but often at additional generation costs. Plant capacity factors range from $40 \%$ to $95 \%$ for power plants suitable for use in providing the baseload (rather than for occasional use to meet peak power demands). ${ }^{13}$

Fields of natural steam are rare. Most are a mixture of steam and hot water requiring single or double flash pressure reduction systems to separate out the hot water, which can then be used in binary plants or for direct use of the heat. ${ }^{6}$ Sustainability concerns relating to land subsidence, heat extraction rates 


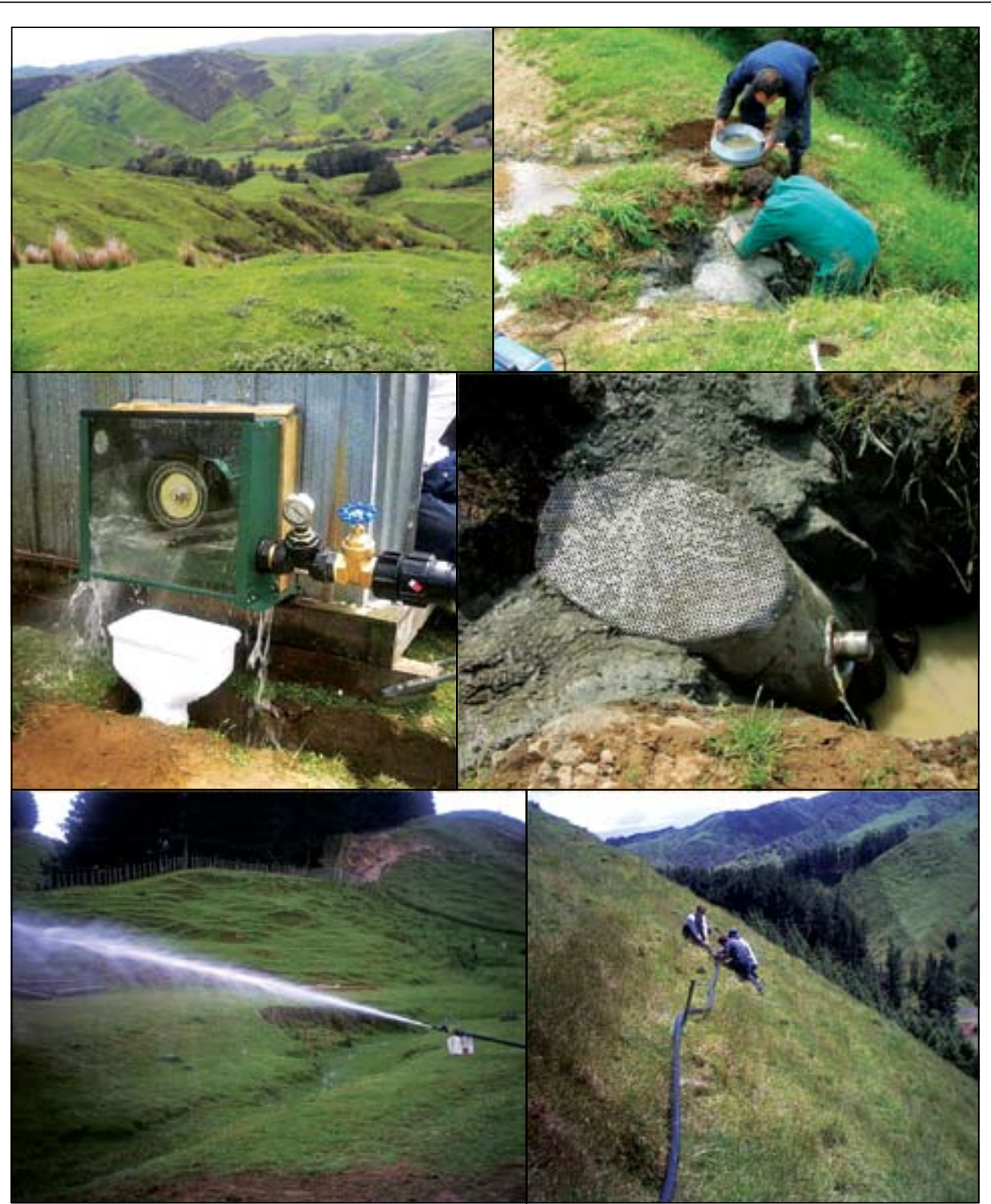

Figure 2. Micro-turbine installation showing (clockwise from top left): site of spring water outlet with local community visible below, installation of the intake to take a portion of total stream flow, intake self-cleaning filter, polyethylene penstock pipe installation, demonstration of water pressure from $140 \mathrm{~m}$ head, and Ecoinnovation turbine ${ }^{12}$ under initial test at over 2,000 rpm (prior to final completion of installation). tical applications for any excess heat. ${ }^{13}$ Power generation costs of large, high-enthalpy geothermal fields running at baseload can be competitive with those of coalfired and gas-fired plants varying in the range of $\$ 30-80 / \mathrm{MWh}^{6}$ Operating costs could increase if the high level of $\mathrm{CO}_{2}$ emissions released from some geothermal bores entail a carbon charge or, indeed, if governments eventually regulate to require carbon dioxide capture and storage. ${ }^{13}$

\section{RD\&D Requirements}

The major difference between traditional electricity and heat generation and the application of geothermal resources is the potentially severe corrosion of metals caused by the geothermal fluids. Chemicals often present that account for most corrosion include oxygen, hydrogen sulfide, ammonia, chloride, sulfates, and hydrogen ions.

Development of better materials for use in downhole equipment for geothermal resource exploitation has continued for more than two decades. Areas of relevance include tubular lining materials, highly alloyed metals, high-temperature cements, high-temperature elastomers, drilling tools, and downwell pumps. Nonmetallic materials such as polymers, concretepolymer composites, and refractory cements could also be used in the development of geothermal fields.

Testing of materials including carbon and stainless steels, titanium, copper, and many alloys needs to be conducted first in the laboratory in brine and with steam temperatures up to $260^{\circ} \mathrm{C}$ and for exposure times of at least two years. Such testing can then be

exceeding natural replenishment, chemical pollution of waterways (e.g., if traces of arsenic are present), excessive warming of river water used for cooling, and associated release of gaseous $\mathrm{CO}_{2}$ emissions from well drilling have resulted in some geothermal power plant permit applications being declined. These concerns could be partly overcome by re-injection of the fluids after heat removal to maintain a more constant pressure in the reservoir in the long term and hence prolong the life of the field.

Capital costs have declined by about $50 \%$ from the $1980 \mathrm{~s}$ level of $\$ 3,000-5,000 / \mathrm{kW}$ for all plant types (with binary cycle plants being the more costly). Power generation costs vary with quality of resource (high-quality being $>250^{\circ} \mathrm{C}$ and low-quality being $<150^{\circ} \mathrm{C}$ ), access to shallow or deep resources, size of field, permit conditions as granted in a resource use consent, and prac- followed by field exposures to ensure that good durability is maintained in the corrosive environment. The American Society for Testing and Materials has been actively involved for over 25 years in this area.

Tests conducted in Japan ${ }^{14}$ for corrosion and scaling of turbine materials assessed six different coatings over a 12-month period. Two types, $\mathrm{Cr}_{3} \mathrm{C}_{2}-\mathrm{NiCr}$ and $\mathrm{Cr}_{3} \mathrm{C}_{2}-\mathrm{FeCrAlY}$, were selected as anti-abrasion coatings, and $\mathrm{Cr}_{3} \mathrm{C}_{2}-\mathrm{NiCr}, \mathrm{ZrB}_{2}$, $\mathrm{CoNiCrAlY}+\mathrm{TiN}$, and $\mathrm{CoNiCrAlY}+\mathrm{Al}_{2} \mathrm{O}_{3} \cdot \mathrm{TiO}_{2}$ were selected as anti-scale-deposition coatings. The anti-abrasion coatings were subjected to corrosion and fatigue tests, whereas the anti-scale-deposition coatings were subjected to only the corrosion tests. Two types of rotor materials, three kinds of blade materials, and one casing material were tested over one year of exposure to geothermal steam. Only one coating experienced 


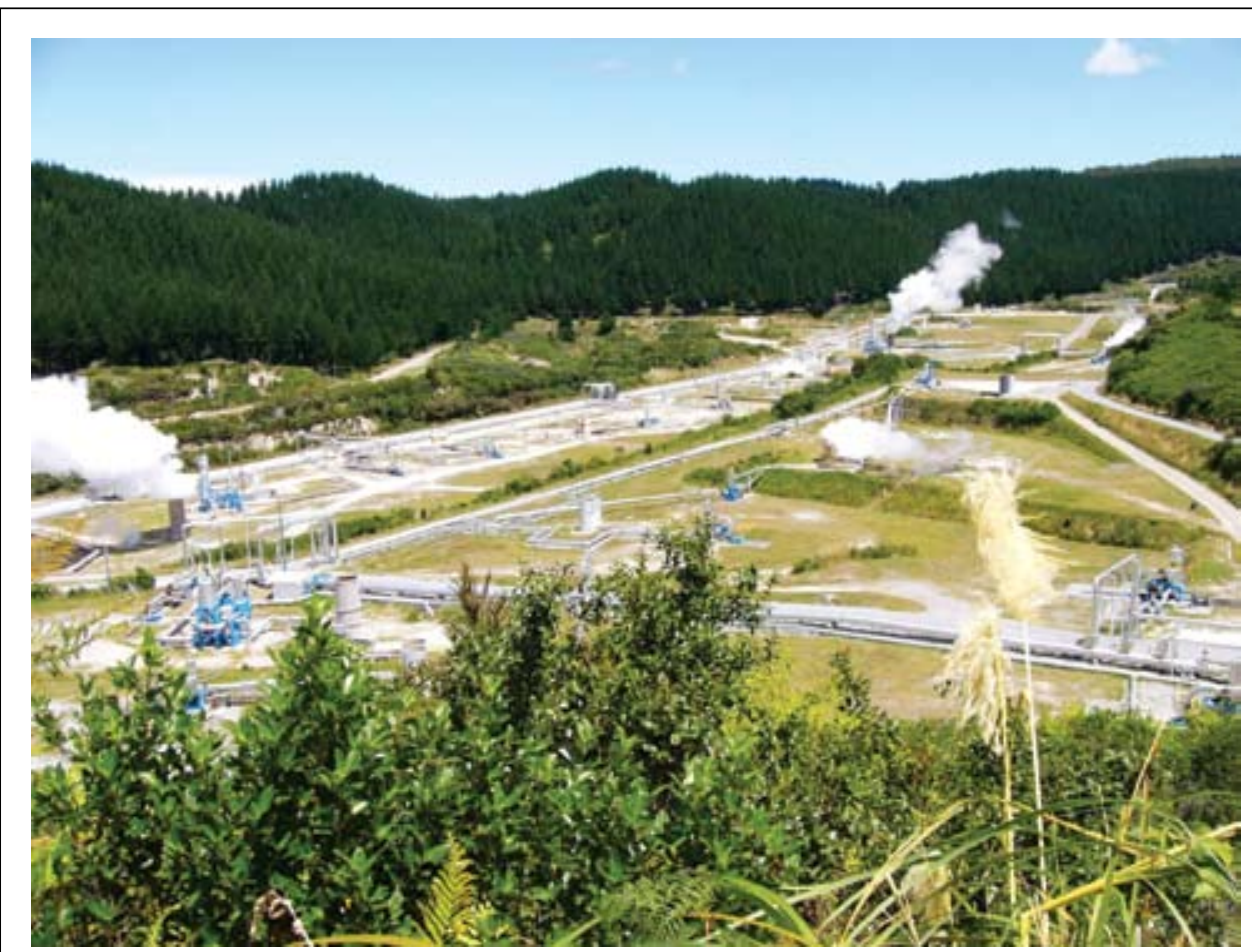

Figure 3. Geothermal field (180 MW) established in 1956 at Wairakei, New Zealand, with bores collecting high-pressure steam for delivery in steel pipes to the power plant located $1 \mathrm{~km}$ away adjacent to the Waikato river used to provide cooling water.
At the small scale, the demand for shallow-well, ground-to-air heat pumps for space heating (and cooling) in buildings is anticipated to increase, especially if the drilling, installation, and hardware costs can be reduced. ${ }^{17}$ Several technologies for shallow geothermal heat extraction are available, including direct flow from a well drilled in the aquifer, horizontal or vertical grids and loops, or even "intelligent" thermal foundations that can automatically absorb or release heat depending on the internal temperature of the building. Costs vary widely according to the choice. Greater consumer usage of these ground heat pumps has already resulted from lower capital costs due to greater mass production and improved heat exchanger loop systems, but such systems remain a costly option. Drilling the bores to install the horizontal or vertical pipes that are used to deposit or extract the heat in the ground can reach up to one-half of the total investment costs. Indeed, improved drilling techniques and bit materials are required. no cracks or separation problems, and only a small amount of scaling was observed on it.

Deeper drilling up to $8 \mathrm{~km}$ to reach molten rock magma resources might become cost-effective in the future, partly depending on materials scientists being able to develop harder wearing drill bits. Deeper and more reliable drilling technology could also help to develop widely abundant "hot dry rocks," where the bedrock is artificially fractured, water is injected, and the heat can then be extracted as steam. Pilot schemes exist but tend not to be cost-effective at this stage, and sites are limited to rock substrates that are sufficiently porous for water to flow through them.

Several advanced energy conversion technologies are becoming available to enhance the use of geothermal heat, including combined-cycle systems for steam resources, trilateral cycles for binary total flow resources, remote detection of hot zones during exploration, absorption/regeneration cycles (e.g., ground heat pumps), and improved power generation technologies. ${ }^{15}$ Enhanced geothermal systems have a long-term potential of $88 \mathrm{GW}$ in the United States alone with $36 \mathrm{GW}$ projected to be developed by 2050 if research and development goals are met. ${ }^{16}$ Cascading multipurpose heat systems that fully utilize the heat by having a range of varying applications as the temperature declines are under further development. The location of the geothermal resource, however, can limit the total heat use if nearby demands for heat for such purposes as food and fiber processing, industry, grain drying, prawn farming, or greenhouse heating do not exist.

It is expected that improvements in characterizing underground reservoirs, low-cost drilling techniques, more efficient conversion systems, and utilization of deeper reservoirs will increase the uptake of geothermal resources, as will the market value for extractable co-products such as silica, zinc, manganese, and lithium. ${ }^{15}$

\section{Ocean Energy}

The potential marine energy resource of wind-driven waves, gravitational tidal ranges, thermal gradients between warm surface water and colder water at depths of $>1,000 \mathrm{~m}$, salinity gradients, and marine currents is huge. ${ }^{18}$ However, technologies designed to capture this energy are mainly prototypes or demonstrations and are far from fully competitive.

The marine energy industry is now in a state of development similar to that of the wind industry in the 1980 s, with existing technologies mainly at an early development and demonstration stage and with an economic potential that is currently very low. ${ }^{19}$ Costs continue to decline as a result of increased learning experience, as was the case over the past decade for wind, solar energy, and bioethanol (Figure 4). However, in order for emerging ocean energy technologies to enter the market, sustained government and public support will be needed. Because oceans are used by a range of stakeholders, the siting of devices will also involve considerable consultation.

The most mature ocean technology is the tidal range barrage, three of which, totaling $260 \mathrm{MW}$ capacity, have generated about $600 \mathrm{GWh}$ /year for almost four decades, with the largest by far located in La Rance, France. In general, such systems employ a barrier in a waterway to exploit the movement of water caused by the rise and fall in sea levels due to tides. As the tide comes in, the water accumulates behind a dam. The gates are then shut as the tide goes out, leaving a stored volume behind the barrage that can then act as a potential energy source once the turbine gates are opened. However, no more such installations are planned because few places in the world have a sufficient tidal range of $>3 \mathrm{~m}$; the economic costs remain high; and environmental impacts on tidal mud flats, wading birds, and invertebrates, for example, all need careful analysis site by site. 


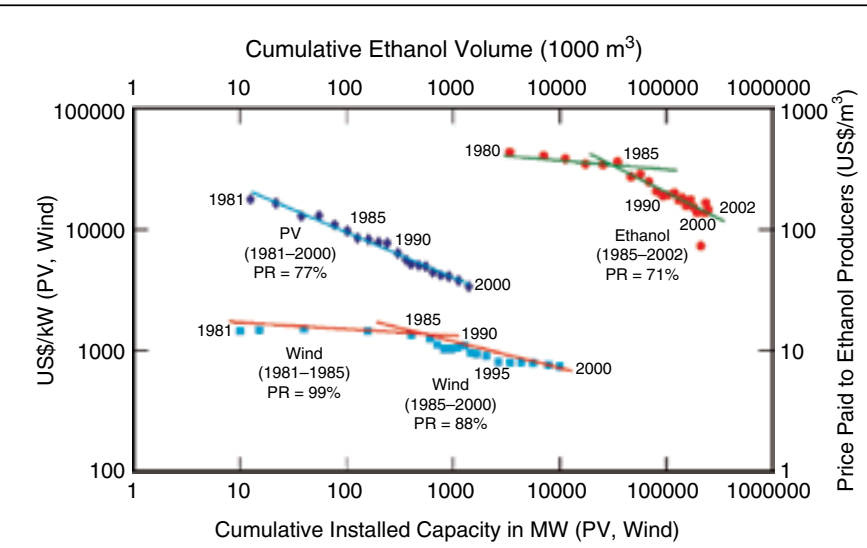

Figure 4. Investment costs and penetration rates (PR) for photovoltaics (PV), wind, and bioethanol systems show that, once the technology has matured, cost reductions of $\sim 20 \%$ for every doubling of capacity result from technological development and learning experience. ${ }^{8}$

The best wave energy climates (Figure 5) exist at the southern tip of South America, in western Australia, and to the west of the British Isles. These areas have deep-water power densities of $60-70 \mathrm{~kW} / \mathrm{m}$, but the values usually decline to about $20 \mathrm{~kW} / \mathrm{m}$ nearer the foreshore. About $2 \%$ of the world's $800,000 \mathrm{~km}$ of coastline exceeds a useful energy density of $30 \mathrm{~kW} / \mathrm{m}$, giving a technical potential of about $500 \mathrm{GW}$, assuming that off-shore wave energy devices have a conversion efficiency of about $40 \%$. However, the economic potential of such systems is estimated to be well below this, ${ }^{20}$ with generating cost estimates of about $\$ 80-110 / \mathrm{MWh}$ at good locations (although these estimates are highly uncertain as no truly commercial-scale plant exists). The only near-commercial wave power projects installed to date total approximately $750 \mathrm{~kW}$ capacity. These have relatively high generation costs, partly because of the facts that designs and materials that can withstand the harsh operating marine environment have to be selected and engineering designs that can withstand extreme storm conditions need to be developed.

Extracting electrical energy from ocean currents could yield in excess of $10 \mathrm{TWh} /$ year $(0.4 \mathrm{EJ} /$ year $)$ if major estuaries with large tidal fluctuations could be tapped. Because the density of water is more than 830 times that of air, an ocean current of just $2.3 \mathrm{~m} / \mathrm{s}$ can produce electricity at a rate equivalent to a mean annual wind speed of $62 \mathrm{~m} / \mathrm{s}$. The best sites in the world with currents about $10 \mathrm{~m} / \mathrm{s}$ are located mainly off of the west coasts

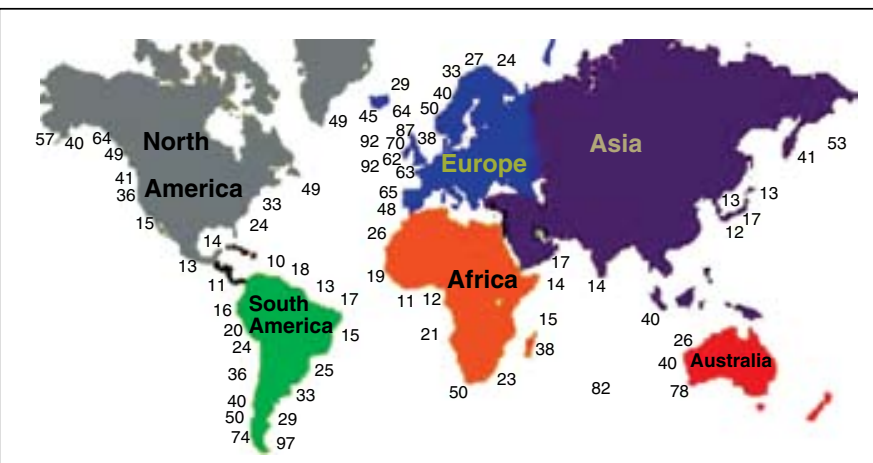

Figure 5. Annual average wave power density flux (in kilowatts per meter in deep water). ${ }^{18}$ of the Americas, the United Kingdom, and Australia, where power fluxes can reach over $80 \mathrm{~kW}$ per meter of coast line. Current cost estimates are relatively high, in the range of $\$ 450$ 1350/MWh. ${ }^{21}$ Preliminary investigations of off-shore currents, such as the very swift Agulhas current off of the coast of South Africa, showed that, on the 100-m-deep seabed, a 1-km stretch of permanent turbines could generate $100 \mathrm{MW}$ of power. ${ }^{22}$

Ocean thermal and saline gradient energy conversion systems remain in the research stage, and it is still too early to estimate their technical potential. Initial applications have been for building air-conditioning systems $\mathrm{s}^{23}$ and for desalination in open- and hybrid-cycle plants using surface condensers. In the future, these technologies could benefit island nations where power is presently provided by expensive diesel generators and sea level rise is causing water supplies to become brackish.

\section{RD\&D Requirements}

The Ocean Energy Implementing Agreement of the International Energy Agency ${ }^{16}$ is entering its second five-year term and has made considerable progress in collaborative ocean energy technology developments. Several demonstration plants now also exist partly as a result of these joint activities. RD\&D requirements relating to materials science include developing water-tight structures, manufacturing reliable components such as thrust bearings and control systems, producing reliable mooring systems and foundations capable of withstanding extreme weather events, developing membranes for salinity gradients, reducing maintenance dangers to enhance safety for the workforce, and avoiding corrosion and marine life growth on the devices.

More than 1,000 patents for wave power machines have been registered, but most remain in the theoretical design stage and only a small number have been tested. The European Marine Test Centre in the Orkney Islands, recently funded by the British government, has several tidal current devices under evaluation, including a $250 \mathrm{~kW}$ on-shore oscillating wave column plant connected to the grid at the Island of Islay. ${ }^{19}$ Tunnels were cut into the cliffs on the shoreline to form the chamber, which captures the energy. In Denmark, a 237 metric ton (t) wave machine with an installed capacity of $18.2 \mathrm{~kW}$ has been undergoing evaluation and testing since 2003. Full-scale 4-11 MW units have since been designed. No fully commercial wave power plants have been built to date, although one is under construction off of the coast of Portugal and other demonstrations are planned in New Zealand, Scotland, Australia, Canada, and elsewhere. ${ }^{18}$

Composites are being developed to make rotor blades and other components of ocean current technologies, ${ }^{24}$ following their successful application for wind turbine blades. Blades are mainly manufactured from carbon fabric and epoxy resin. However, the increased blade loading from water (up to $3 \mathrm{t} / \mathrm{m}^{2}$ for a $2.5 \mathrm{~m} / \mathrm{s}$ current) compared to air loads on wind turbine blades makes blade strength and stiffness more critical. The environmental impacts on sea flora and fauna are claimed to be negligible, ${ }^{25}$ but remote off-shore locations, the high labor costs for divers, and the challenge of working in fast currents make the cost of repair and maintenance relatively high. Hence, greater reliability and less wear are keenly sought by manufacturers.

For ocean thermal energy conversion systems, biofouling control and corrosion in high-thermal-conductivity materials, such as copper alloys and stainless steel used in heat exchangers and conductors in near-surface warm water and deep cold water, are the two issues that need major consideration. Research has been ongoing for at least two decades, including work by the U.S. Department of Energy, ${ }^{26}$ but further reliability over long lifetimes and at minimal costs is still being sought. 


\section{Conclusions}

Hydro and geothermal energy systems are well-established and efficient, but improvements in plant and turbine designs are still sought to incrementally reduce costs and improve component reliability. Ocean energy systems, on the other hand, are mainly at an early stage of development, and many technical challenges exist because of the challenging natural environment in which they operate. Materials research can have further applications in the development of all three technologies and help make progress toward the overall aim to make the necessary transition to low-carbon-emitting energy technologies.

\section{References}

1. Intergovernmental Panel on Climate Change, in Climate Change 2007: Mitigation. Contribution of Working Group III to the Fourth Assessment Report of the Intergovernmental Panel on Climate Change, B. Metz, O.R. Davidson, P.R. Bosch, R. Dave, L.A. Meyer, Eds., (Cambridge University Press, Cambridge, UK, 2007), ch. 4.

2. International Energy Agency, World Energy Outlook 2006 (OECD/IEA, Paris, 2006; www.iea.org/Textbase/publications/free_new_Desc.asp?PUBS_ $I D=1804$ ) (accessed January 2008).

3. International Energy Agency, Deploying Renewables-Principles for Effective Policies" (OECD/IEA Paris, 2008), forthcoming report in May 2008. 4. S. Ölz, R. Sims, N. Kirchner, Contribution of Renewables to Energy Security (OECD/IEA, Paris, 2007; www.iea.org/textbase/papers/2007/so_contribution. pdf) (accessed January 2008)

5. PoliticalDeclaration/InternationalActionProgramme/Policy Recommendations for Renewable Energy presented at the Proceedings International Conference for Renewable Energies, Bonn, Germany, 1-4 June 2004; www.renewables2004.de (accessed January 2008).

6. World Energy Council, 2006 Survey of Energy Resources (WEC, London, 2006).

7. T.B. Johansson, K. McCormick, L. Neij, W. Turkenburg, paper presented at the International Conference for Renewable Energies, Bonn, Germany, 2004; www. renewables2004.de/pdf/tbp/TBP10-potentials.pdf (accessed January 2008). 8. E. Martinot, Renewables Global Status Report 2006 Update (Renewable Energy Policy Network, Worldwatch Institute, Washington, DC, 2006; http:// www.ren21.net/pdf/RE_GSR_2006_Update.pdf) (accessed January 2008).

9. International Hydropower Association, IHA Sustainability Assessment Protocol (IHA, London, 2006; www.hydropower.org/blue_planet_prize/ compliance_protocol.html) (accessed January 2008).
10. International Energy Agency, IEA Hydropower Implementing Agreement (IEA, Paris, 2007).

11. International Energy Agency, Renewable Energy: RD\&D Priorities Insights from IEA Technology Programmes (OECD/IEA, Paris, 2006; www. iea.org/Textbase/publications/free_new_Desc.asp?PUBS_ID=1592) (accessed January 2008).

12. M. Lawley, Ecoinnovation Limited; www.ecoinnovation.co.nz (accessed January 2008).

13. R. Bertani, in Proceedings of the World Geothermal Congress 2005, Antalya, Turkey, 24-29 April 2005.

14. H. Kato, K. Furuya, M. Yamashita, in Proceedings of the World Geotherma Congress, Kyushu-Tohoku, Japan, May 28-June 10, 2000.

15. International Energy Agency, "The IEA Geothermal Energy Implementing Agreement" (IEA, Paris, 2007; www.iea-gia.org/geo_agreement_gia.asp) (accessed January 2008).

16. U.S. Department of Energy, Projected Benefits of Federal Energy Efficiency and Renewable Energy Programs (FY2006-FY2050), Long-Term Benefits Analysis of EERE's Programs (U.S. Department of Energy, Washington, DC, 2005), ch. 5

17. International Energy Agency, "Renewables for Heating and Cooling Untapped Potential" (OECD/IEA, Paris, 2007; www.iea.org/textbase/nppdf/ free/2007/Renewable_Heating_Cooling.pdf) (accessed January 2008).

18. International Energy Agency, "Ocean Energy Systems Implementing Agreement" (International Energy Agency, Paris, 2007; www.iea-oceans.org) (accessed January 2008).

19. Carbon Trust, "Marine Energy - The Next Big Opportunity for Your Technology?"(Carbon Trust, London, 2005; www.carbontrust.co.uk) (accessed January 2008).

20. National Renewable Energy Laboratory, Energy Analysis Office, "Renewable Energy Cost Trends" (NREL, Golden, CO, 2006; www.nrel.gov/ analysis/docs/cost_curves_2005.ppt) (accessed January 2008).

21. Wavegen Co. Ltd. (2007); www.wavegen.com (accessed January 2008). 22. W. Nel, Feasibility of Energy Plant in Agulhas Ocean Current (Eskom Report No. RES/SC/03/22509, Eskom Holdings Ltd., Johannesburg, South Africa, 2003).

23. Makai Ocean Engineering, "Deep Pipelines for Ocean Thermal Energy Conversion" (Makai Ocean Engineering, 2007; www.makai.com/p-otec.htm) (accessed January 2008).

24. Composites Technology (2007); www.compositesworld.com (accessed January 2008).

25. K.F. Mason, Compos. Technol. 44 (December, 2005); www.compositesworld. com/ct/issues/2005/December/1120 (accessed January 2008).

26. J.B. Darby, Proc. Conference on 'Materials for Future Energy Systems,' Washington (May 1984).

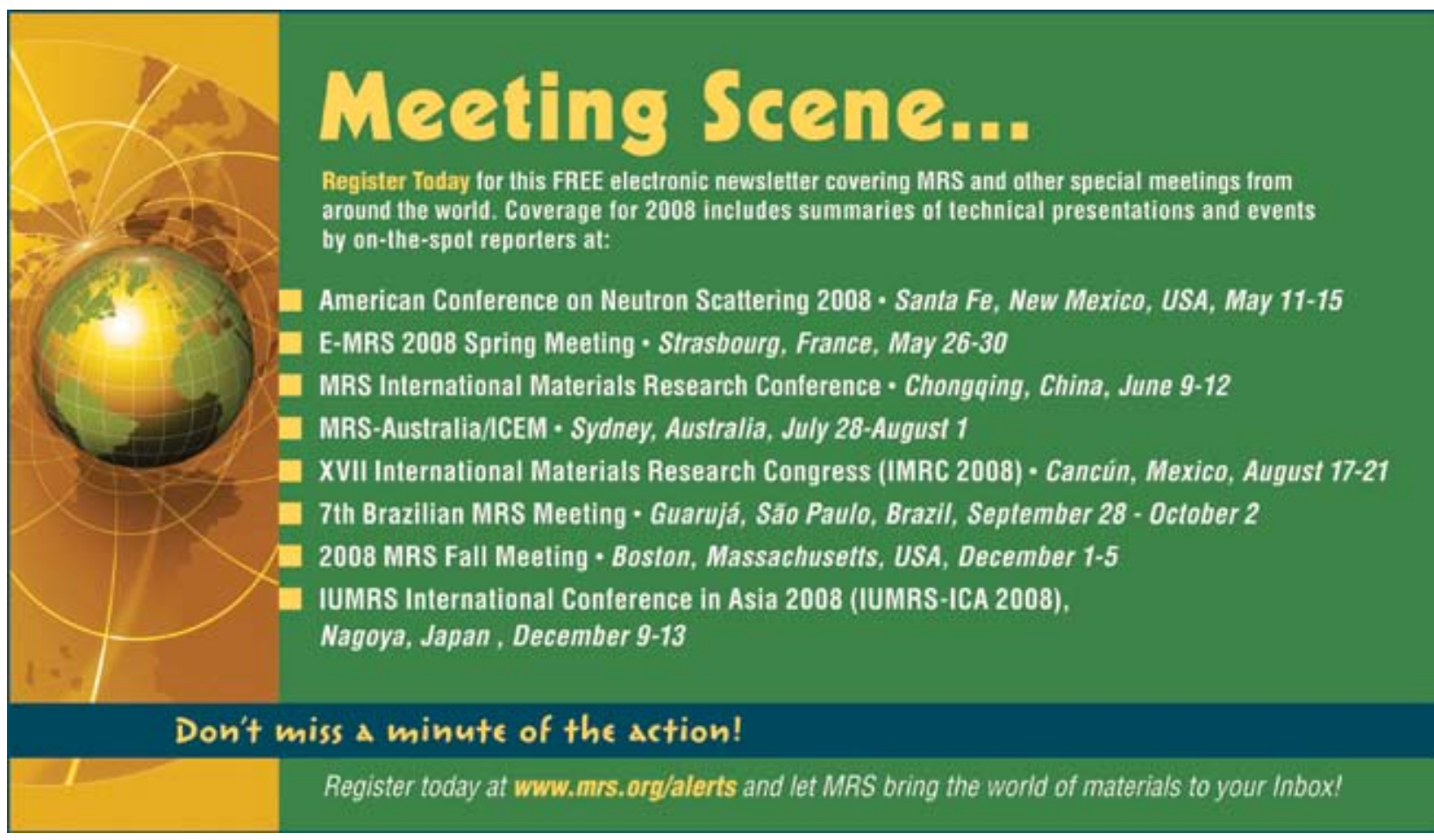




\section{A Wide Range of Versatile Nano Technology Solutions}

\section{Enjoy Productivity, Reliability and Precision}

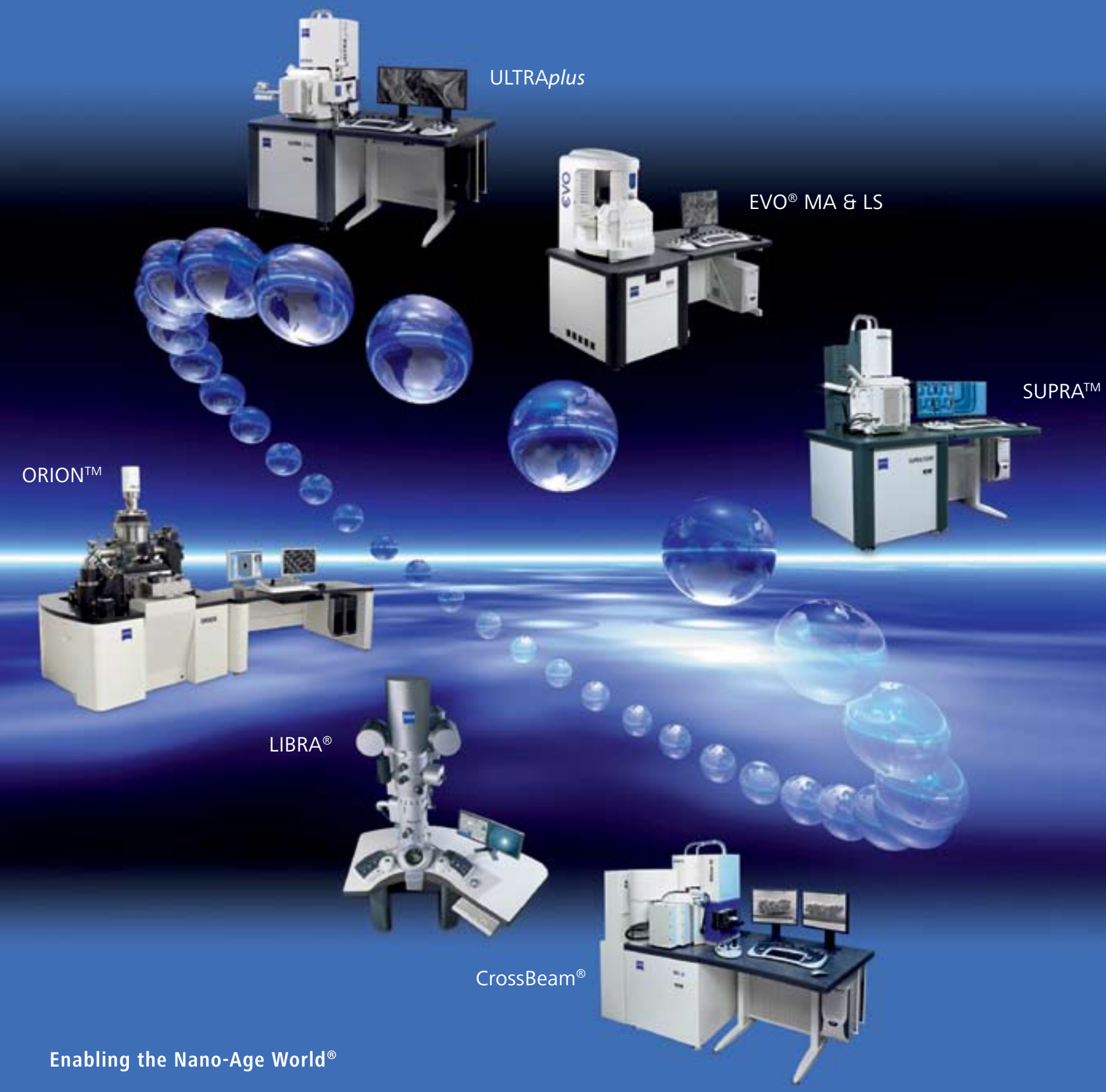

